\title{
The Eye of the Machine: Labor Sciences and the Mechanical Registration of the Human Body
}

\author{
Frederik Herman and Karin Priem
}

1

Introduction: “The New Messiah" in a School Attic

A few years after our first visit to the Lycée Technique Privé Emile Metz, we visited the school again in the spring of 2017. Established in 1913/14, the Institut Emile Metz (as it was called at the time) soon evolved into a progressive and prestigious school for vocational education and professional training. Our second visit to the school was very rewarding, as the renovation work that was underway allowed us to explore parts of the premises that had not been accessible to visitors before. During our first visit in 2013, we had discovered an ergometric bicycle (see fig. 5.1) in the school's attic. The second exploration revealed a few more objects that had once belonged to the school's psychophysiological laboratory and exhibition room, including a mercury manometer and two

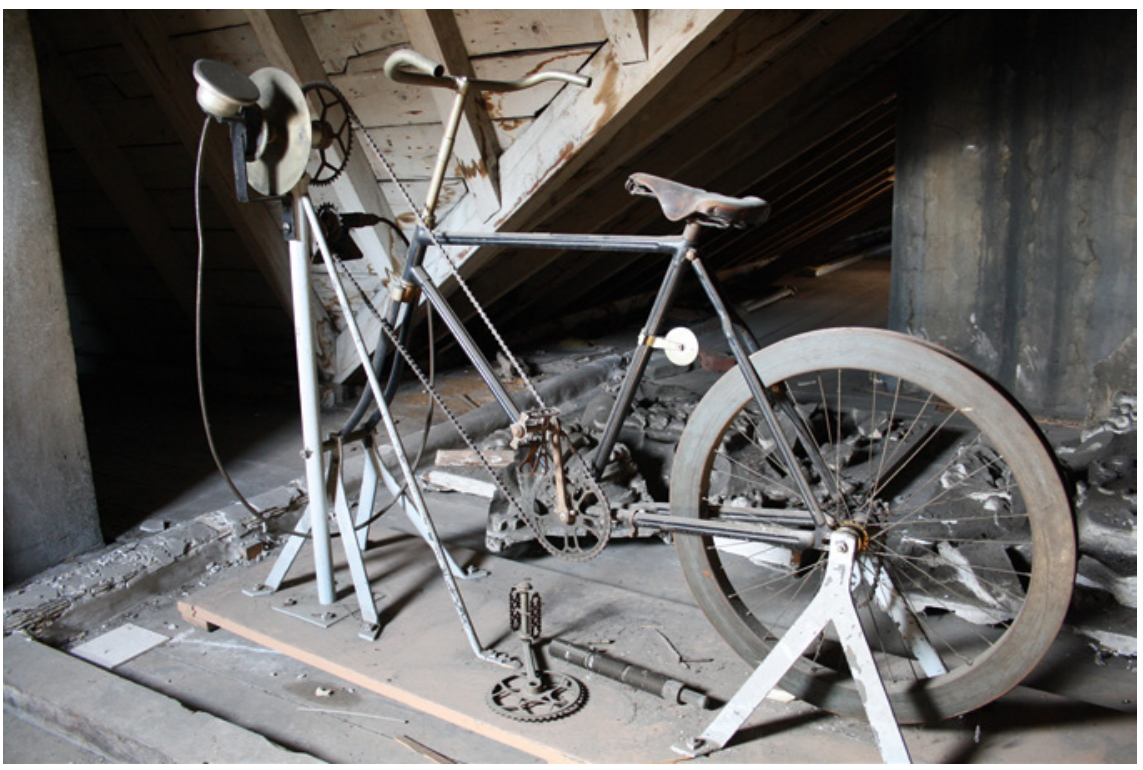

FIGURE 5.1 Ergometric bicycle in the attic of the Lycée Technique Privé Emile Metz. PHOTOGRAPH. (C) FREDERIK HERMAN.

(C) FREDERIK HERMAN AND KARIN PRIEM, 2019 | DOI:10.1163/9789004410510_007

This is an open access chapter distributed under the terms of the GC-BY-NC 4 o License 


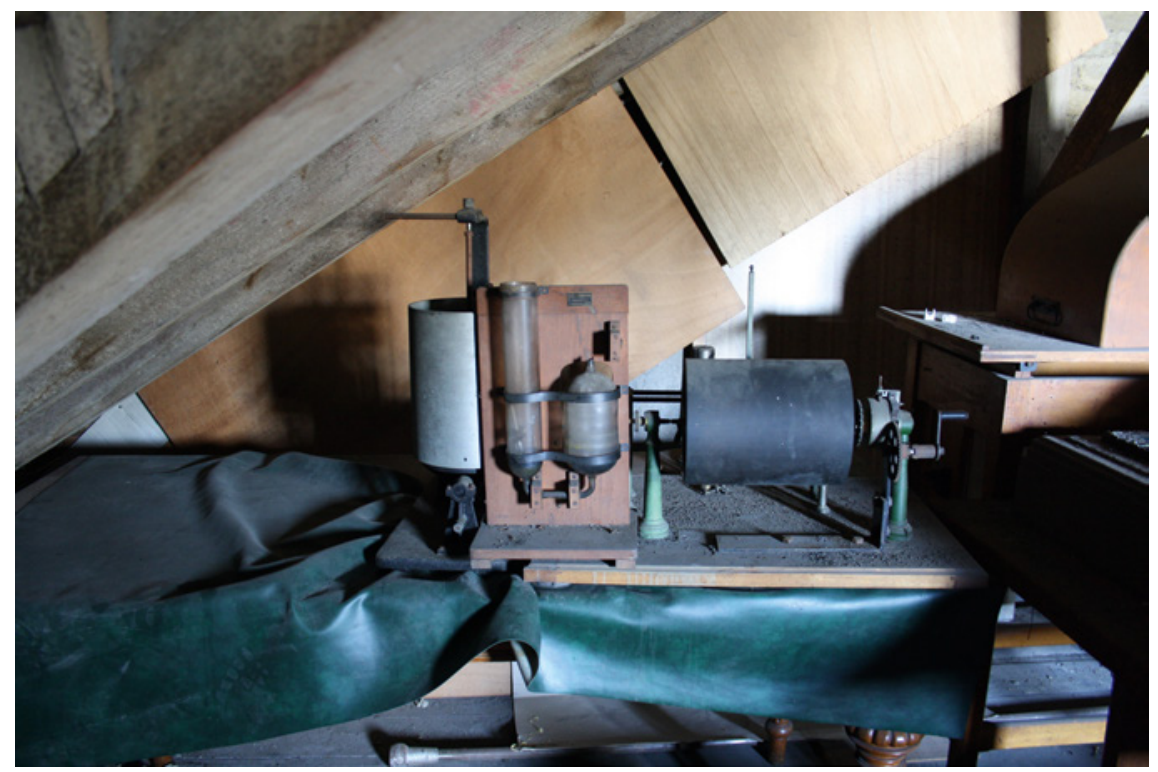

FIGURE 5.2 Mercury manometer (front) and two cylindrical recorders. Spring 2017. PHOTOGRAPH. (C) FREDERIK HERMAN.

cylindrical recorders (see fig. 5.2) as well as a sophisticated scale model of the labyrinthine school building. ${ }^{1}$ The school's psychophysiological laboratory had also left behind other material traces, including a huge glass plate collection containing a staged photograph of the laboratory equipment "at work" in the $1920 s$ (see fig. 5.3). Dating back to the early days of the institute, these almost "forgotten" pieces of the school's educational heritage were emblems of the age of industrialization, mechanization, and frantic scientific developmentsa period in which machines became the "new Messiah" and science the new "religion" promising a utopian mechanized paradise. ${ }^{2}$

The nineteenth and twentieth centuries were the cradle of a new religion. Paul Strand, an American modernist photographer and filmmaker, referred to these secular-religious tendencies of modern times by ironically equating the

1 For more information on the establishment of the school and the laboratory, see Frederik Herman, "Forging Harmony in the Social Organism: Industry and the Power of Psychometric Techniques," History of Education 43, no. 5 (2014): 592-614.

2 Henry Ford, "Machinery, the New Messiah," Forum (March 1928): 359-64. See also Philipp Blom, Alleen de wolken: Cultuur en crisis in het Westen, 1918-1938, trans. Pon Ruiter and Henny Corver (Amsterdam: De Bezige Bij, 2014), 235-41, for a discussion of the famous Soviet Taylorist Aleksei Gastev, founder and director of the Central Institute of Labor in Moscow in the $1920 s$. 


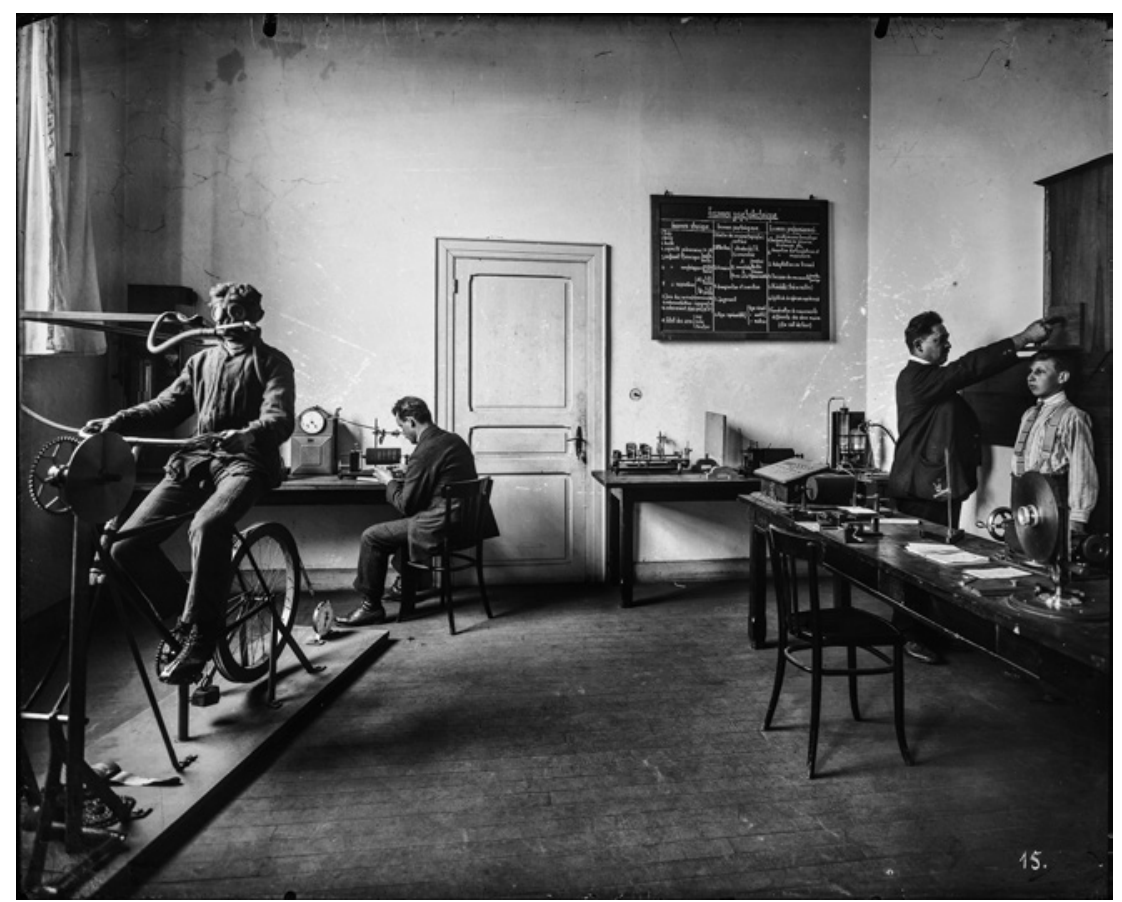

FIGURE 5.3 Psychophysiological laboratory at the Institut Emile Metz: On the left, a young man is training on an ergometric bicycle. In the background, on the right, one can see three cylindrical recorders and the mercury manometer. Digital positive from glass plate negative.

(C) INSTITUT EMILE METZ. CNA COLLECTiON.

"machine" with "God," "materialistic empiricism" with the role of Jesus the "son," and "science" with the "holy ghost."3 Moreover, technological and scientific developments gave birth to the transhuman, posthuman, or what has been called cyborgs. ${ }^{4}$ In The Vertigo Years, a book on the massive societal transformations at the beginning of the twentieth century, Phillip Blom writes: "Man and machine entered into a strange marriage, a fused, bionic body, a second creation." 5

3 Paul Strand, "Photography and the New God," Broom 3, no. 4 (1922): 252.

4 In her famous 1985 article, Donna J. Haraway described a cyborg (cybernetic organism) as a "fusion of the organic and the technical forged in particular, historical, cultural practices." See Donna J. Haraway, "A Manifesto for Cyborgs: Science, Technology, and Socialist Feminism in the 1980s," Socialist Review 8o (1985): 65-107. See also Donna J. Haraway, "Modest_Witness @ Second_Millenium," in The Social Shaping of Technology, 2nd ed., ed. Donald MacKenzie and Judy Wajcman (Buckingham: Open University Press, 1999), 41-49.

5 Philipp Blom, The Vertigo Years: Change and Culture in the West, 1900-1914 (London: Phoenix, 2009), 401. 
Indeed, industrialization, mechanization, and techno-scientific evolutions gradually came to intertwine the organic with the artificial/machinic and thus revolutionized the established Western ideals of the organic order. ${ }^{6}$ It was believed (at least by the post-humanists) that the dyad of technology and science would make it possible to create a new, reconfigured, and enhanced mankind. These promises aimed to mitigate the harsh critique of science which had emerged simultaneously at the turn of the twentieth century. Indeed, scientification was not yet generally recognized as a secular replacement for the omnipresent eye of God. However, as a result of the gradual secularization and loss of power of the church following the Reformation, scientific, empirical thinking found space for expression. ${ }^{7}$ One major step in fulfilling the promise of scientific research was to gain eternally valid knowledge by replacing the subjective, naked human eye of the scientist with "the eye of the machine." ${ }^{8}$

It was a frantic time in which "scientific observers continually honed the techniques and technologies they employed to observe the external and internal world, at some times discarding the old as they developed the new and at other times simply redefining in what observation consisted." ${ }^{\prime 9}$ The empirical examination of the human body and mind - not least by the post-1848 generation of physiologists and (experimental) psychologists-required tools of mechanical objectivity, such as cameras, collimators, chronometers, and calipers. ${ }^{10}$ Technological developments-such as motion photography or chrono-photography, cinematography, and dynamography ${ }^{11}$ —enabled mechanical registration, which would usher in modernist objectivity. ${ }^{12}$ The new machine-mediated observation gradually came to supplement or even replace

6 See Katherine N. Hayles, How We Became Posthuman (Chicago: University of Chicago Press, 1999); Chris Hables Gray, Cyborg Citizen: Politics in the Posthuman Age (New York: Routledge, 2002).

7 Strand, "Photography and the New God," 252.

8 Ibid.

9 Lorraine Daston and Elizabeth Lunbeck, "Observing in New Ways: Techniques," in Histories of Scientific Observation, ed. Lorraine Daston and Elizabeth Lunbeck (Chicago: University of Chicago Press, 2011), 181.

10 See Lorraine Daston and Peter Galison, Objectivity (New York: Zone Books, 2007), 258. See also Vincent Borella, "Les corps entre mécanique et machines," in Corps et machines à l'âge industriel, ed. Laurence Guignard, Pascal Raggi, and Etienne Thévenin (Rennes: Presses Universitaires de Rennes, 2011), 255-56.

11 One of the pioneers of visual studies of human and animal locomotion was the English photographer Eadweard Muybridge (1830-1904). For more information on Muybridge, see Hans Christian Adam, ed., Eadweard Muybridge: The Human and Animal Locomotion Photographs (Cologne: Taschen, 2014).

12 See Theodore M. Porter, Trust in Numbers: The Pursuit of Objectivity in Science and Public Life (Princeton, NJ: Princeton University Press, 1995). 
the embodied experiences of the observer. Indeed, before the age of the observing machines, observation was still based on the capacity and function of the human eye and the ability to feel empathy with the observed subject. In his article "Seeing the Blush: Feeling Emotions," Otniel E. Dror argues that "the observer's capacity to visceral-embodied mirroring of the observed was transplanted to the machine."13 $\mathrm{He}$ then goes on to describe this radical shift:

[Machine-mediated] observation worked by transplanting the visceral activations of the observed subject not into the body of the observer, but into an exteriorized entity - the machine. The machine literally projected the visceral activations of the observed subject outside of the body in terms of graphic tracings or numeric tables. Instead of observing through self-embodied experiences, observers looked at the embodied visceral physiology of experience through the mediation of machines and in terms of graphs and numbers. The mechanical effects ... of the beating of the heart literally pushed and moved the sensitive mechanical registering apparatus, which transcribed these visceral movements into graphs. ${ }^{14}$

A strong urge for "visual realism," which led to the development of all kinds of graphic methods of display, was a logical response to the growing impulse to record, visualize, and quantify as much data as possible in fields ranging from science, population studies, and health to economics and industry to crime. ${ }^{15}$ Statistical material and graphic representations "were valued for their capacity to summarize large amounts of extensive and abstract information in a striking "image" and were said to be "transparent forms of representation that offered the viewer unmediated access" to the observed subject. ${ }^{16}$ The late nineteenth and early twentieth centuries were a period when "observing machines" became the new "lens" through which to inspect reality. Machine-produced graphs that replaced the sensory vision of experts, as well as statistics that replaced the knowledge-based expertise of individual researchers, were equated with objectivity and thus became the expert's main thinking pattern (brain) within the decision-making process. ${ }^{17}$

13 Otniel E. Dror, "Seeing the Blush: Feeling Emotions," in Daston and Lunbeck, Histories of Scientific Observation, 336 .

14 Ibid., 337.

15 Anders Ekström, “'Showing at One View': Ferdinand Boberg's 'Statistical Machinery' and the Visionary Pedagogy of Early Twentieth-Century Statistical Display," Early Popular Visual Culture 6, no. 1 (2008): 46; Miles A. Kimball and Charles Kostelnick, eds., Visible Numbers: Essays on the History of Statistical Graphics (Farnham, UK: Ashgate, 2016).

16 Ekström, "Showing at One View," 46.

17 Of course, the rise of statistical theory, statistical thinking, and statistical graphics have their roots in a more distant past. Michael Friendly has called the second half of 
These new and abstract geometrical ways of seeing and (re)presenting were designed to serve scientific purposes and also played a major role in teaching and training. ${ }^{18}$ They emerged within and/or were almost immediately adopted by the then nascent sciences, such as experimental psychology and labor science, as well as associated (sub)disciplines including psychophysiology, psychometrics, pedology, and fatigue studies. ${ }^{19}$ Both scientists and artists shared a desire to capture human movements through abstraction, serial geometric (de)construction, lines, cubes, graphs, polygones, and numbers to represent the living and moving human body and its energy. Indeed, there was a tendency to experiment with the "translation" of "realistic" or naturalistic body movements into abstract, serial graphs as a way to discover basic patterns that could be generalized and essentialized. What was once familiar was translated into unfamiliar and abstract images that invited new ways of observing. Marcel Duchamp's 1912 painting Nude Descending a Staircase, No. 2, for example, was inspired by the chronophotographs of Etienne-Jules Marey and Eadweard Muybridge who both experimented with photographic image series to explore the basic principles of human movement and energy. Other artists like Sonia and Robert Delaunay explored the rhythm and energy of movements through vibrant and colorful abstract forms that were inspired by the frantic pace of modern life. ${ }^{20}$ As such, scientific experiments were part of a larger social and cultural context, and scientists and artists were united in a common endeavor

the nineteenth century the "golden age of statistical graphics" and the period we are dealing with "the modern dark ages of data visualization," as the initial enthusiasm for these graphics diminished during the first half of the twentieth century; see Michael Friendly, "The Golden Age of Statistical Graphics," Statistical Science 28, no. 4 (2008): 502-35. See also Frederik Herman, Karin Priem, and Geert Thyssen, "Body_Machine? Encounters of the Human and the Mechanical in Education, Industry and Science," History of Education 46, no. 1 (2017): 108-27; Kurt Danziger, Constructing the Subject: Historical Origins of Psychological Research (Cambridge: Cambridge University Press, 2002); Porter, Trust in Numbers; Gérard Jorland, Annick Opinel, and George Weisz, eds., Body Counts: Medical Quantification in Historical and Sociological Perspectives/Perspectives historiques et sociologiques sur la quantification médicale (Montreal: McGill-Queen's University Press, 2005).

18 See Ekström, "Showing at One View"; and, in this volume, Karin Priem and Frederik Herman, 'Sensuous Geographies' in the 'Age of Steel': Educating Future Workers' Bodies in Time and Space (1900-1940)."

19 For an excellent reference work on the early years of experimental psychology/pedagogy and pedotechnics, see Marc Depaepe, Zum Wohl des Kindes? Pädologie, pädagogische Psychologie und experimentelle Pädagogik in Europa und den USA, 1890-1940 (Leuven: Leuven University Press; Weinheim: Deutscher Studien Verlag, 1993).

20 See Tate Modern Exhibition \& Events, "The Ey Exhibition: Sonia Delaunay, 15 April-9 August 2015," http://www.tate.org.uk/whats-on/tate-modern/exhibition/sonia-delaunay. 
to express, understand, and put on display forces or phenomena that were invisible to the human eye. ${ }^{21}$

\section{$2 \quad$ Reading and Charting Apprentices' Bodies at the Institut Emile Metz}

This chapter explores a specific case in the context of professional orientation, vocational training, and rehabilitation - the early twentieth-century technoscientific experiments of the French labor physiologist, industrial ergonomist, and fatigue expert Jules (Mardochée) Amar (1879-1935), who saw his mission in life as uncovering and establishing the scientific foundations of human labor. ${ }^{22}$ Observing machines-designed "to read the body" - as well as graphic and numerical representations were key to this mission and would, moreover, guarantee the desired mechanical and structural objectivity. ${ }^{23}$ Amar advocated a moderate Taylorism and the humanization of labor at a time when the rationalization of labor had made its turbulent entry into Europe and led to fierce workers' strikes. In Amar's eyes, science (experimental psychology and, more specifically, psychophysiology and psychotechnology) would provide the solution and result in harmony and productivity by helping to eliminate, among other things, industrial fatigue or overfatigue (surmenage). ${ }^{24}$

21 Charles Kostelnick, "Melting-Pot Ideology, Modernist Aesthetics, and the Emergence of Graphical Conventions: The Statistical Atlases of the United States, 1874-1925," in Defining Visual Rhetorics, ed. Charles A. Hill and Marguerite Helmers (Mahway, NJ: Lawrence Erlbaum Associates, 2004), 215-42.

22 Jules Amar's work includes: Le rendement de la machine humaine: Recherches sur le travail (Paris:J.-B. Baillière, 1909); Le moteur humain et les bases scientifiques du travail professionnel (Paris: Dunod et Pinat, 1913/14); "La rééducation des blessés et mutilés de la guerre," Revue scientifique 54 (1916): 363-67; "Physical and Psychological Tests-Organization of the Training of the Disabled," T. M. Canada-Special Bulletin (1916): 29-42; Le devoir agricole et les blessés de guerre (Paris: Dunod et Pinat, 1917); Organisation physiologique du travail (Paris: Dunod et Pinat, 1917); "Titres et travaux scientifiques" (unpublished manuscript, Faculté de Médecine de Paris, 1919, вIU Santé, Paris); The Human Motor, or The Scientific Foundations of Labour and Industry, trans. Elsie P. Butterworth and George F. Wright (London: George Routledge \& Sons; New York: E. P. Dutton \& Co., 1920); Jules Amar and Paul Painlevé, La prothèse et le travail de mutilés: Conférence faite pour les Oeuvres de Mutilés (Paris: Dunod et Pinat, 1916).

23 Alexandre Klein, "Lire le corps pour percer l'âme': outils et appareils à l'aube de la psychologie scientifique à Nancy," in Guignard, Raggi, and Thévenin, Corps et machines à l'âge industriel, 41-54. Unless otherwise noted, all translations are the authors' own.

24 See also François Vatin, "Les 'sciences du travail': une tentative de résolution positiviste de la question sociale," Bulletin de psychologie 61, no. 496 (2008): 331-40; François Vatin, "Du travail à la fatigue, genèse et échec de la psycho-physiologie du travail," Bulletin de psychologie 49, no. 425 (1996): 520-29; Nicolas Pitsos, "Le moteur humain en panne s'affiche: 
We begin with a brief biographical sketch of the "forgotten" transhumanist Jules Amar. ${ }^{25}$ This section also provides insight into Amar's views on society and mankind and his strong beliefs in the trainability and rehabilitation of man. It does so by exploring the transhumanist, rehabilitative discourses, practices, and devices (e.g., prosthetics) that he developed in the context of the First World War. The next two sections will deal with Amar's strong belief in observing machines-as "prosthetic" extensions of the observer's sensesas well as in the structural objectivity ostensibly brought about by the use of numbers, graphs, statistics, and differential equations. We will look at, among other things, Amar's mechanical observation and registration of apprentices' bodies by means of a dynamographic "Imbert-Amar" file, as well as the use of mechanically generated geometric and abstract charts and graphs in the context of the Institut Emile Metz. ${ }^{26}$ Indeed, the institute's laboratory, established in 1919, used the innovative measuring and training apparatuses and methods developed —or at least inspired—by Amar for its program of professional orientation and vocational training. Throughout their school career, apprentices at the Institut Emile Metz were subjected to all kinds of measurements and tests that mapped their physical dimensions and their physical and psychological functions (see fig. 5.3). ${ }^{27}$ In this context, the generated numbers, lines, and graphs became the tools par excellence for "making judgements, drawing

le corps épuisé au tournant du XIX siècle," in Guignard, Raggi, and Thévenin, Corps et machines à l'âge industriel, 289-300.

25 Indeed, despite his major contributions to the labor sciences in France, Amar ended up being overshadowed by his contemporaries such as the (psycho-)physiologists and industrial psychologists (Jules Adolphe) Georges Weiss (1859-1931), Jean-Marie Lahy (18721943), Henri (Louis) Le Châtelier (1850-1936), and Josefa Ioteyko (1866-1928). See Hugues Monod and Janine Monod, "Jules Amar (1879-1935)," Histoire des sciences médicales 13, no. 3 (1979): 231; Michel Valentin, Travail des hommes et savants oubliés: Histoire de la médecine du travail, de la sécurité et de l'ergonomie (Paris: Editions Docis, 1978). Amar's work has received more attention since its rediscovery by Prof. Dr. Hugues Monod, Prof. Dr. Christine Théré, and Prof. Dr. François Vatin from the Université de Paris Ouest, who are preparing an anthology on the labor sciences in France from Guillaume Amontons (16631705) until Jules Amar. Incidentally, the book cover of Le moteur humain and a (graffiti) portrait of Jules Amar are currently decorating the entrance to the infirmary of the Paris Conservatoire national des arts et metiers (CNAM).

26 Herman, "Forging Harmony in the Social Organism." See also Françoise Poos, "Photography as a Space for Constructing Subjectivities: Luxembourg's Steel Dynasties and the Modern Workforce as Seen through the Glass Plate Negatives from the Institut Emile Metz" (in this volume).

27 See Herman, "Forging Harmony in the Social Organism"; Herman, Priem, and Thyssen, "Body_Machine?," 108-27; Frederik Herman, Karin Priem, and Geert Thyssen, "Körper_ Maschinen? Die Verschmelzung von Mensch und Technik in Pädagogik, Industrie und Wissenschaft," Jahrbuch für Historische Bildungsforschung 20 (2015): 47-75. 
conclusions, proposing rectification"-practices that would significantly determine the future of these apprentices. ${ }^{28}$

Amar was born in a modest home in Tunis on November $14,1879 .{ }^{29}$ After graduating in literature and philosophy, he went to Paris in 1898, where he completed numerous courses in botany, biochemistry, general chemistry, general physiology, and mineralogy at the Sorbonne. ${ }^{30}$ In 1905, Amar became an assistant at the Medical Physics Laboratory of the Medical Faculty in Paris under the supervision of the physiologist Georges Weiss. ${ }^{31}$ Shortly afterwards, he was appointed director of the laboratory, a position he would hold until 1913. In 1907, he agreed to undertake a scientific mission for the Ministry of Public Instruction and, in the same year, was tasked with another long-term mission by the Ministries of Public Instruction and of Labor to examine the working capacities of prison inmates at Biskra, Algeria. More specifically, he was to determine the optimal efficiency of the "human motor" in relation to food consumption and digestion. ${ }^{32}$ During the same period, he completed his doctoral thesis, published under the title Le rendement de la machine humaine (The yield of the human machine, 1909), in which he elaborated on physical and mental fatigue and the optimal but economical expenditure of human energy in the context of labor. Shortly afterwards, in 1911, Amar was appointed a member of the Commission on the Physiology of Labor at the Ministry of Labor, ${ }^{33}$ which was established in response to the introduction of Taylorism in France around 1910 and was tasked with scrutinizing the harmful effects of

28 Thomas S. Popkewitz, "The Empirical and Political 'Fact' of Theory in the Social and Education Sciences," in Making a Difference in Theory: The Theory Question in Education and the Education Question in Theory, ed. Gert Biesta, Julie Allan, and Richard Edwards (London: Routledge, 2014), 13-29.

29 Monod and Monod, "Jules Amar (1879-1935)," 227.

30 Amar, "Titres et travaux scientifiques," $1-2$.

31 Ibid. For more biographical details, see also Valentin, Travail des hommes et savants oubliés, 291-96; Monod and Monod, "Jules Amar (1879-1935)"; Georges Ribeill, "Les débuts de l'ergonomie en France à la veille de la Première Guerre mondiale," Le mouvement social 113 (1980): 14-16; Anson Rabinbach, The Human Motor: Energy, Fatigue and the Origins of Modernity (Berkeley: University of California Press, 1992); Hugues Monod, "Amar, Jules (1879-1935)," in Les professeurs du Conservatoire National des Arts et Métiers: Dictionnaire biographique 1794-1955, vol. 1, ed. Claudine Fontanon and André Grelon (Paris: INRP/CNAM, 1994), 97-107.

32 Rabinbach, The Human Motor, 158, 185 .

33 Amar, "Titres et travaux scientifiques," 1-2. 
industrialization on the workers. ${ }^{34}$ In 1913, a temporary Research Laboratory on Muscular Activity in the Context of Labor was founded at the National Conservatory of Arts and Crafts for the same purpose. The same year, Amar was appointed director of this psychophysiological laboratory. ${ }^{35}$

In 1913/14, he published his key work, Le moteur humain et les bases scientifiques du travail professionnel (The Human Motor, or The Scientific Foundations of Labour and Industry), in which he linked the human organism in the context of labor to the laws of general mechanics and modern physiology and elaborated on, among other things, the "architecture" of the human body, the muscular motor, nutrition and energy expenditure, the productivity of the human machine, the physiological effects of work (notably fatigue), balance and movements of the human body at work, and man and the environment. ${ }^{36}$ His work soon became the basis for human engineering in Europe and the United States. ${ }^{37}$ Amar clearly strove for "social efficiency" or a "moderate Taylorism." ${ }^{38}$ He was not so much interested in industry's blunt quest for maximum productivity, which would inevitably result in exhausted and demoralized workers, but rather in adapting the working conditions to the workers' physical aptitudes and in rigorously training their bodies so that they would achieve physical and mental balance and harmony and thus function optimally and tirelessly. Amar's main concern was achieving the most economical use of energy and, thus, the maximum amount of work with the minimum amount of energy expenditure. ${ }^{39}$ Accurate and objective experimental physiological measurements and data would allow the scientific adjustment of human bodies to the workplace, providing insights into the level of fatigue and energy consumption and making it possible to identify a predetermined optimum.

34 Monod and Monod, "Jules Amar (1879-1935)," 230.

35 Ibid.; see also Régis Ouvrier-Bonnaz, "L'histoire des chaires du CNAM concernant l'Homme au travail (1900-1945) entre production de savoirs et engagement politique," $C a$ hiers d'histoire: Revue d'histoire critique 111 (2010): 99-121. For the sake of completeness, it should be mentioned that Amar was also a member of the Orthopaedic Commission of the Ministry of War, of the National Office of Mutilated Persons, and of the Committee for the Improvement of the Training of the Maimed at the Ministry of Labor.

36 Herman, Priem, and Thyssen, "Körper_Maschinen?," 49.

37 Reinhard Klette and Garry Tee, "Understanding Human Motion: A Historic Review," in Human Motion: Understanding, Modelling, Capture and Animation, ed. Bodo Rosenhahn, Reinhard Klette, and Dimitris Metaxas (Dordrecht: Springer, 2008), 13.

38 Rabinbach, The Human Motor, 128; Herman, "Forging Harmony in the Social Organism," 610 .

39 Rabinbach, The Human Motor, 188; Raf De Bont, "Energie op de weegschaal: Vermoeidheidsstudie, psychotechniek en biometrie in België (1900-1945)," Belgisch Tijdschrift voor Nieuwste Geschiedenis/Revue Belge d'Histoire Contemporaine 32, nos. 1-2 (2002): $23-71$. 
Excessive energy consumption was attributed to factors such as wrong body posture or inappropriate movements, incorrect manipulation of tools, maladjusted speed or pressure. An optimal functioning could be achieved by synchronizing the workers' performance with a science-based norm or "prototype" and by complying with detailed instructions formulated by Amar on the basis of a series of trial experiments.

The "human motor" metaphor used by Amar to link bodies and machines on the eve of the First World War foreshadowed the literal connections he would make between the mutilated soldiers and the mechanical prosthetics during and after the war. ${ }^{40}$ Indeed, the First World War caused Amar to (re-)orient his focus towards rehabilitative practices and to apply his scientific expertise in the entangled fields of experimental psychology, psychophysiology, biomechanics, and fatigue studies to the design of prostheses, the restoration of mutilated bodies through mechanical limbs, and the vocational orientation and training of the maimed heroes. ${ }^{41}$ It became Amar's pioneering mission to render the muscular male bodies of the "glorious victims" again capable of performing useful work in different sectors. ${ }^{42}$ In Amar's opinion, all

40 See Herman, Priem, and Thyssen, “Körper_Maschinen?"; Jacques Gleyse et al., "Physical Education as a Subject in France (School Curriculum, Policies and Discourse): The Body and the Metaphors of the Engine-Elements Used in the Analysis of a Power and Control System during the Second Industrial Revolution," Sport, Education and Society 7, no. 1 (2002): 5-23; Katja Patzel-Mattern, "Menschliche Maschinen - Maschinelle Menschen? Die industrielle Gestaltung des Mensch-Maschine-Verhältnisses am Beispiel der Psychotechnik und der Arbeit Georg Schlesingers mit Kriegsversehrten," Würzburger medizinhistorische Mitteilungen 24 (2005): 378-90.

41 See Amar and Painlevé, La prothèse et le travail de mutilés, 2; "The Training of Maimed Soldiers," The Engineer, June 9, 1916, 472-73. Amar's ideas on rehabilitation would prove influential for the actual practices of rehabilitation during and after the war. His methods were applied, for instance, at the Military Professional School for Mutilated Belgians in Port-Villez (France), at the Centers of Manual Labor and Workshops in Rouen (France), which was affiliated with the Anglo-Belgian Hospital Roi Albert I set up to accommodate wounded allies, and at other écoles de rééducation professionnelle in France and Italy. See Amar, "La rééducation des blessés et mutilés de la guerre," 367; Amar, "Physical and Psychological Tests," 32. For more information on these rehabilitative practices and the experiences of maimed soldiers in these institutes, see Pieter Verstraete and Frederik Herman, "A Plea for Commonality: Disability History, Discourses of Rehabilitation, and the Individual," Asclepio: Revista de Historia de la Medicina y de la Ciencia 68, no. 2 (2016): n.p.

42 Compared to its neighboring countries, France lagged behind, as it lacked a network of specialized institutes (for example, ateliers-écoles pour les estropiés) as well as systematized and comprehensive programs for the physical rehabilitation of veterans. See J. McLennan, "Introduction," T. M. Canada-Special Bulletin (1916): 5; Émile GaltierBoissière, Larousse médical illustré de guerre (Paris: Librairie Larousse, 1917), 2; see also 
bodies - young and old, abled and disabled, male and female — could be improved as "principal sites of a man's productive value." ${ }^{33}$ All bodies were malleable and mendable and thus could become subjects of objective observation and training with regard to (re-)employment. Human bodies and the rhythm of the machine imposed by society's and industry's quest for maximum productivity had to be harmonized and optimized. ${ }^{44}$ Indeed, as Verstraete and Herman have suggested, "all members of the community were thought of as being defective or even 'crippled' and had to be turned into a science-based prototype of the inexhaustible and efficient worker along the same trajectory of authoritative psychophysiological and medical testing and training." Neither Amar's general focus on harmonizing industrial production nor the methods he applied distinguished between able and maimed bodies, as he saw the maimed soldiers as part of a "crippled" society that, suffering from a loss of energy and a lack of knowledge on the mechanics of the human body, needed to be made efficient (again). This is shown by the fact that he used the same or similar measuring and training devices and aptitude cards, whether testing prison inmates, maimed soldiers, or apprentices of a vocational school. Rather than focusing on the distinction between the psychologically and/or physically disabled and abled, his rehabilitative discourse centered on the learning capabilities, trainability, and level of skillfulness of all members of the workforce.

Rabinbach, The Human Motor; Gordon Hughes and Philipp Blom, Nothing but the Clouds Unchanged: Artists in World War I (Los Angeles: The Getty Research Institute, 2014). Amar's experimental approach, the devices (e.g., the cheirograph, the dynamographic bulb, ergometric cycle and arthrodynameter) and prostheses (e.g., working arm) he developed, and the ideas he elaborated on vocational orientation and retraining processes in his capacity as director of the newly created Laboratory for Military Prosthesis and Occupational Labor (1915) had international reverberations. See, for instance, W. M. Dobell, "Report on European Work," T. M. Canada-Special Bulletin (1916): 11-28; McLennan, "Introduction"; "The Training of Maimed Soldiers"; Leo de Paeuw, Vocational Reeducation of Maimed Soldiers (Princeton, NJ: Princeton University Press, 1918), 144; Monod, "Amar, Jules"; Roxanne Panchasi, "Reconstructions: Prosthetics and the Rehabilitation of the Male Body in World War I France," Differences: A Journal of Feminist Cultural Studies 3, no. 3 (1995): 109-40; Elspeth H. Brown, "The Prosthetics of Management: Motion Study, Photography, and the Industrialized Body in World War I America," in Artificial Parts, Practical Lives: Modern Histories of Prosthetics, ed. Katherine Ott, David Serlin, and Stephen Mihm (New York: New York University Press, 2002), 249-81; Clément Collard, "Que faire des 'héros vaincus'? - La rééducation professionnelle des mutilés de la Grande Guerre 1914-1940" (master's thesis, Institut d'études politiques de Paris, 2014).

43 Roxanne Panchasi, Future Tense: The Culture of Anticipation in France between the Wars (Ithaca, NY: Cornell University Press, 2009), 23.

Priem and Herman, "'Sensuous Geographies' in the 'Age of Steel." 
During and after the First World War, Amar took his strong belief in the learning capabilities and trainability of man, which was rooted in his pre-war research, to another level. Amar believed that the majority of the maimed soldiers could be rehabilitated and again become full and "complete" members of society (hommes complets) after undergoing thorough psychophysiological training. ${ }^{45}$ His training program, which, in his view, had to be offered as soon as the wounds were healed, consisted of three main stages. Throughout the rehabilitation process, the physical, psychological, and intellectual capacities were carefully observed, recorded, and trained. ${ }^{46}$ During the first phase of "functional restoration," Amar aimed to combat muscle and joint stiffness and muscle atrophy and to render the tendons and cartilage tissue flexible again through a systematic and cumulative physiological training program using exercise machines. His "intelligent mechanical therapy" was based on scientific motion studies conducted with the aid of recording tools and/or self-recording training devices. ${ }^{47}$ Symbolizing faith in unceasing scientific progress, these tools and devices enhanced reliability and objectivity and made it possible to record the recovery process. ${ }^{48}$ Not only the mutilated limb but the entire body-the sensory organs, heart, lungs, and central nervous system - were subjected to a thorough medico-physiological screening to optimize their capacity for work. Determining the organic defects and the remaining physical abilities and improving the condition of the entire body were essential in the fight against fatigue. Special emphasis was put on the training of the mutilated limb, or the "sensitive training of the stump."49 Performing progressive movement exercises with the help of training and measuring devices could correct these deficiencies. In this phase, mental, sensory and behavioral "re-programming" were key. During the second phase, the so-called prosthetic phase, the maimed received their mechanical $\operatorname{limb}(\mathrm{s}) \cdot{ }^{50}$ Functionality of the prosthesis always took precedence over aesthetics, as the lost function and thus productive value had to be restored by means of a practical prosthesis, which was customized with

45 Amar and Painlevé, La prothèse et le travail de mutilés, 2.

46 Amar, "Physical and Psychological Tests," 31.

47 Amar and Painlevé, La prothèse et le travail de mutilés, 7.

48 Ibid., 9.

49 Galtier-Boissière, Larousse médical illustré de guerre, 4-6, 36.

50 Amar designed and patented a lot of artificial limbs, such as the 'articulated hand' and the 'working arm'; see Monod and Monod, "Jules Amar," 22; Gilles Colas des Francs, L'oeuvre de Jules Amar entre 1914-1918 (Paris: Reprocopy, 1984). It was this 'working arm,' a prosthesis to which a series of basic tools and a natural-looking parade hand (main de parade) could be attached, that made Amar famous on both sides of the Atlantic; see Panchasi, Future Tense, 19-20. 
the goal of using human energy and the existing factory equipment as efficiently as possible..$^{51}$ The last phase of the occupational rehabilitation began once the owner had sufficiently familiarized himself with his new mechanical limb. This stage consisted of three modules: theoretical training, handicrafts, and in-service training. Both theoretical and general education had to awaken the disabled soldier's latent intelligence and raise his intellectual level, which would in turn enhance body coordination. Courses dealt with topics such as the selection of proper tools for specific tasks and the operation of machines. ${ }^{52}$

"Under experimental conditions, with mathematical and scientific rigor, Amar studied the mechanics of the human body in microscopic detail," both in the laboratory and on the factory floor. ${ }^{54}$ Indeed, he strongly believed that achieving the maximum and optimal use of the nation's resources would require rational and scientific methods and devices. ${ }^{55}$ Key to Amar's approach was the permanent gathering of physiological data during the rehabilitation and training processes by means of a variety of advanced observation, measuring, and training apparatuses, many of which he invented himself while also refining existing devices. ${ }^{56} \mathrm{He}$ extensively described these specialized and advanced ergographic and dynamographic apparatuses in various publications. ${ }^{57}$ In the

$51 \quad$ Brown, "The Prosthetics of Management," 335; Panchasi, "Reconstructions."

52 See Amar and Painlevé, La prothèse et le travail de mutilés, 15.

53 Sigmund Freud, Civilization and Its Discontents, trans. David McLintock (London: Penguin Books, 2004), 39 .

54 Rabinbach, The Human Motor, 187. For a brief overview of the history of the experimental method, its devices, and its key figures, such as the founding father of positivism, the French philosopher Auguste Comte (1798-1857), and the French physiologist Claude Bernard (1813-1878), see Klein, "Lire le corps pour percer l'âme," 52-53.

55 Amar and Painlevé, La prothèse et le travail de mutilés, 4.

56 See also Rabinbach, The Human Motor, 185. Interestingly enough, despite the fact that efficient, rhythmical, and precise body movements were key to Amar's approach (see Priem and Herman, "'Sensuous Geographies' in the 'Age of Steel"), he did not apply already existing photographic or cinematographic methods such as chronophotography and chrono-cyclography. In his Le moteur humain, he devoted only a short section to these techniques, stating that these approaches-which had indeed "resolved in a most striking and beautiful way the problems of kinetics" —were only appropriate for 'movement studies'; see Amar, Le moteur humain, 14-16.

57 The following descriptions of the devices are mainly based on Jules Amar, The Physiology of Industrial Organisation and the Re-Employment of the Disabled, ed. A. F. Stanley Kent, trans. Bernard Miall (London: The Library Press Limited, 1918), 147-59. 
following, we will take a closer look at three examples: the cheirograph, the dynamographic bulb (poire dynamographique), and the ergometric cycle (cycle ergométrique). ${ }^{58}$

Amar's cheirograph - a modification of the Italian physiologist Angelo Mosso's digital ergograph - was designed to measure the variety of hand movements, from the wrist to the fingers, and the muscle power used during these movements (see fig. 5.4) ${ }^{59}$ The test consisted of repetitively pulling, by means of a cord, a weight which was attached to a specific part of the hand (e.g., finger or wrist), while the hand and forearm were partly immobilized by a kind of brace. Each flexion generated a curve. The final graph expressed the number of contractions, the rhythm, and the degrees of displacement of the weight. The rhythm as well as the intensity of the contractions (the swing of the curve) gradually decreased as a result of the test subject's fatigue. This negative effect could be postponed through progressive training. Indeed, Amar wrote, "thanks to this apparatus, the hand, that delicate segment of the upper limb, so well adapted to movements involving skill and celerity, may be subjected to a functional education, for whose results ... we have not very long to wait."60

Amar also transformed all kinds of ordinary utensils into scientific observation and training devices by connecting them to a dynamograph, turning them into dynamographic tools - such as, for example, the dynamographic hammer, slicer, file, typewriter, pencil, bulb, and sidewalk (see fig. 5.5) — which

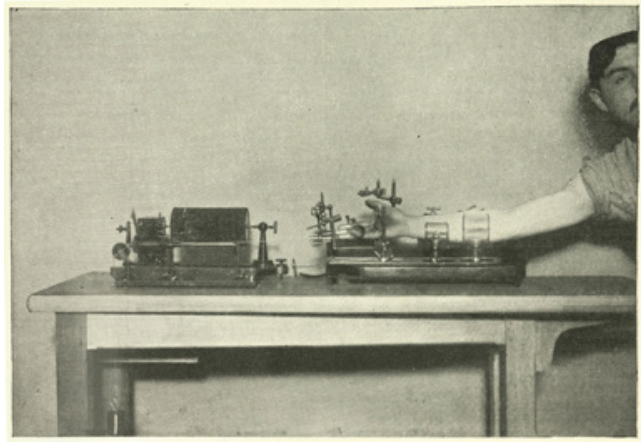

FIGURE 5.4

Arrangement of Amar's cheirograph test. Reprinted from Galtier-Boissière, Larousse médical illustré de guerre (1917), 63 .

$5^{8} \quad$ For a description of other devices and tests such as, for example, the perforating test, the coordination test with a two-hand coordinator, and the hammering and filing test, see Priem and Herman, "Sensuous Geographies' in the 'Age of Steel."

59 For more information, see Amar, Le moteur humain, 391; Amar, The Physiology of Industrial Organisation, 151-54; Galtier-Boissière, Larousse médical illustré de guerre, 62-64.

6 Amar, The Physiology of Industrial Organisation, 151. 


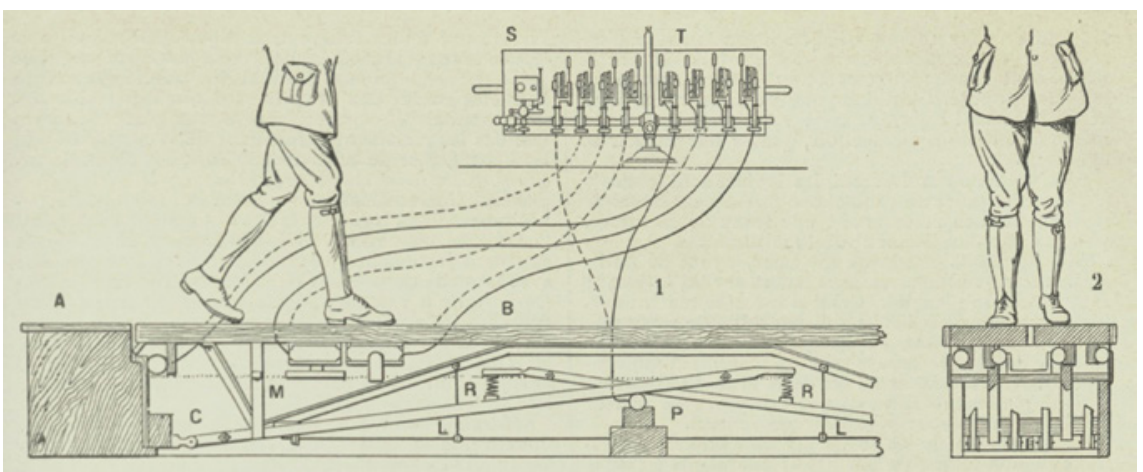

FIGURE 5.5 Illustration of Amar's dynamographic sidewalk.

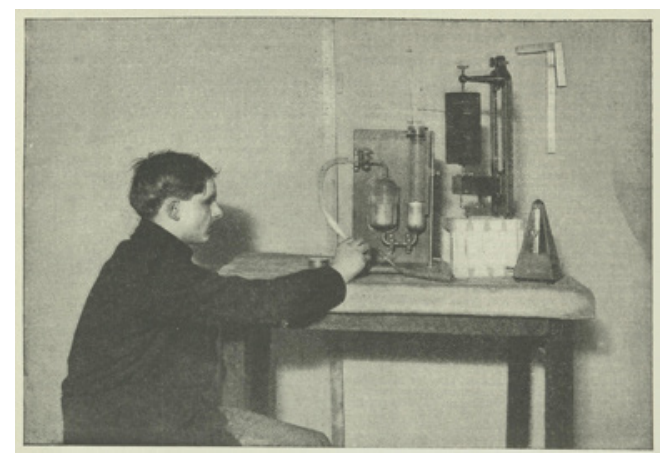

FIGURE 5.6

Arrangement of Amar's dynamographic bulb exercise. Reprinted from Galtier-Boissière, Larousse médical illustré de guerre (1917), 319 and 244.

recorded the rhythm of the movements and the force used during the performance while also generating dynamographic graphs. ${ }^{61}$ Everyday objects and materials as sites of everyday experience thus continued to be at the heart of experimentation settings. A typical example is the "synergetic training" of the hand with the aid of a dynamographic bulb or bulb dynamometer (see fig. 5.6). The test subject was asked to repeatedly squeeze a rubber bulb connected to a mercury manometer and a cylindrical recorder (cylindre enregistreur), which plotted a graph providing information on the rhythm, the pressure exercised with the fingers, the persistence of the pinch, and the level of fatigue. ${ }^{62}$ Amar

61 The dynamographic sidewalk (trottoir dynamographique) plotted the movement of and the pressure exercised by the legs in motion. For an illustration and more technical details, see Galtier-Boissière, Larousse médical illustré de guerre, 319-20.

62 "This [device] consists of a strongly-made pear-shaped bulb of Indiana-rubber having a capacity of 125 cubic centimeters. This is filled with air at any desired pressure by means of a cycle pump. It is connected with a mercury manometer, one of whose arms is capacious enough to contain at least 500 cubic centimeters of mercury, while the other 
also designed an ergometric cycle (today called a friction-cycle ergometer; see figs. 5.2 and 5.5) to study the human metabolism, the expenditure of energy, and the degree of fatigue. ${ }^{63}$ The bicycle was the perfect apparatus to record the amount of work performed by the muscles of the legs, but it could also be used (after some transformations) to test and train the arms or even mutilated limbs. ${ }^{64}$ Moreover, Amar also used it to collect other medical and physiological data - with the aid of additional devices, such as, for example, a cardiograph, respirator, or spirometer. ${ }^{65}$

Since Amar did not believe that the observer's eye and/or empathy were perfect, he extended the observer's senses and embodied experience through machine-mediated observation, employing a fleet of observation apparatuses. ${ }^{66}$ Scientific research thus was no longer possible without a laboratory and relevant apparatuses. ${ }^{67}$ The promise these (ergographic) tools held out to the scientist was described by Amar in The Human Motor as follows:

Errors are reduced both by the accuracy of the instruments employed, and their frequent calibrations, and also by arranging that, where possible, they shall be self-recording. The demands on the attention of the observer are thereby greatly reduced and the possibility of visual errors in observation eliminated. ${ }^{68}$

branch, which is longer, contains about 30 cubic centimeters. This latter contains a registering float, so that all displacements of the mercury caused by the pressure of the finger, above the known pressure of the air in the bulb, are recorded on a registering cylinder .... The oscillations of the mercury are damped by a constriction in the tube connecting the two arms. The difference of level in the two arms measures the total pressure.... The compression of the fingers causes a variation of the initial pressure, and the variations furnish a tracing which is graduated once and for all.... [This device makes] it possible to follow the advance of functional fatigue as the hand continues its exertions and also the rhythm of movements." Amar, The Physiology of Industrial Organisation, 154-56. For more technical details, see also Galtier-Boissière, Larousse médical illustré de guerre, 244-45.

63 For a historical overview of this device, generally used in medical and physiological testing and/or (aerobic) training, and the different kinds of ergometers, see Henry Vandewalle and Tarak Driss, "Friction-Loaded Cycle Ergometers: Past, Present and Future," Cogent Engineering 2 (2015): 1-35.

64 See also Herman, Priem, and Thyssen, “Body_Machine?"; Verstraete and Herman, "A Plea for Commonality."

65 A typical example is the apprentice wearing a gas mask while performing the cycle test, as shown in fig. 3 .

66 See Dror, "Seeing the Blush: Feeling Emotions," 336.

67 See Klein, "Lire le corps pour percer l'âme," 52.

68 Amar, The Human Motor, 262-63. 
So it was not only the maimed who needed prostheses; the scientific observer, too, was in need of prosthetic devices which would allow him/her to "see" and more broadly "sense" through the machine what otherwise would remain invisible to the naked eye or "escape the observer's senses," to remember or to keep track of the subject's development, and, finally, to judge accurately and objectively. 69

Indeed, Amar was striving for what one can call "mechanical objectivity."70 He wanted to capture the energy flow in the human body at work and to register the inner workings of body and mind with as little human intervention as possible - that is, unmediated by language and untainted by subjective projections. ${ }^{71}$ According to Amar, the researcher could trust the mechanical evidence of the self-recording measuring devices, which supplemented the direct, naked-eye observation of bodies in action (reality) and allowed a posteriori observation of the mediated reality (graphs). Thus Amar distinguished several, partly overlapping observation phases: (1) direct, naked-eye observation of the action by the researcher; (2) observation and registration of the ongoing action through the eye of the machine; (3) examination of the generated graphs while the test subject performs the test; and, finally, (4) a posteriori analysis and interpretation of the generated graphs.

\section{Abstracting Bodies: Dots, Graphs, Numbers, and Differential Equations}

Amar's apparatuses generated graphs-linear representations of rhythm, amount of force expended, etc.- - over a certain period of time. These geometric and graphic forms made it possible to both analyze the evolution of the performance (over time) on the spot and later compare it with other registered performances (of the same subject or peers). It thus recorded, visualized, and "materialized" experiences that otherwise would have "evaporated." Moreover, these graphs visualized the smallest nuances that could not be seen with the naked eye. Indeed, they opened up a new dimension of observing and perceiving reality. It could be argued that this kind of mediated reality had an artifical character, as the phenomenon only took on the appearance of a phenomenon

\footnotetext{
$69 \quad$ Ibid., 265.

70 We have borrowed this concept from Daston and Galison, but use it in a slightly different way in the sense that we refer to the moment of registration rather than to the visualmaterial result (e.g., micro-photograph). See Daston and Galison, Objectivity, 18, 20.

71 Ibid., 20, 43 .
} 
and became "real" as a result of the mechanical registration and inscription devices. ${ }^{72}$ The abstract representations of the body's movement-by means of dots, graphs, numbers, and differential equations-were simultaneously seen as evidence of an otherwise unnoticeable reality. Amar strove to make experiences and "data more visible to the eye and memorable to the mind." ${ }^{73}$ Indeed, in his opinion, the quantitive data portrayed in graphs were "transparent" learning tools. ${ }^{74}$ He writes:

I had to create several accurate and uncomplicated apparatuses, which have proven to obtain good results.... This technique has the advantage that it is directly appealing to the eyes and reliable; it is based on graphic registration, which allows to evaluate the muscular strength and to see the evolution. It thus reveals, at any time, the progress made. ...

Great lessons can be derived from them for both training and work, and real practical suggestions for the worker who enjoys observing and seeking clarity. In his eyes, the model, graphically and impersonally taught, has a sovereign value; it outperforms written or verbal explanations. ${ }^{75}$

Like many other nineteenth- and early twentieth-century scholars from a wide array of disciplines such as statistics and mathematics, political economy, engineering, sociology, physical science, and medicine, Amar strove to quantify human labor and physical endeavor, and to use the "visual display of quantitative information" —or visible numbers, in Kostelnick and Kimball's phrase - to gain insight into human bodies at work. ${ }^{76}$ Neutral numbers or dots on a graph, stripped of qualitative and subjective projections, became his main tool to engineer a science-based prototype of the ideal worker (l'ouvrier modèle), taking the Belgian statistician Adolph Quetelet's "average man" (l'homme moyen) to another level, from normality to ideality. ${ }^{77}$ The measurable construct of the

72 Bruno Latour and Steve Woolgar in this context refer to Bachelard's notion of 'phenomenotechnique,' which implies that phenomena are often "thoroughly constituted by the material setting of the laboratory"; see Bruno Latour and Steve Woolgar, Laboratory Life: The Construction of Scientific Facts (Princeton, NJ: Princeton University Press, 1986), 64.

73 Kostelnick and Kimball, "Introduction," in Kostelnick and Kimball, Visible Numbers, 1.

74 Amar, "Physical and Psychological Tests"; Amar, "Titres et travaux scientifiques," 11.

75 Amar and Painlevé, La prothèse et le travail de mutilés, 7, 15.

76 Edward R. Tufte, The Visual Display of Quantitative Information (Cheshire, CT: Graphics Press, 1983); Kimball and Kostelnick, Visible Numbers.

77 Researchers usually interpreted their data on the basis of an a priori model of universal equilibrium. In an encyclopaedia entry on the bell curve, Lynn Fendler writes that Adolphe Quetelet "assumed that social phenomena would show the same regularity as 
"efficient" model worker-based on large-scale observations ${ }^{78}$ — became the prevailing frame of reference for testing and training future workers.

Figure 5.7 shows a poster entitled "Exercices rationnels d'entrainement au travail à la lime bâtarde" (Rational training exercises to manipulate the bastard file). It displays the mechanically registered "ideal" results obtained by the instructor as well as the two test results of four locksmith apprentices (A, B, C, S) with five months of training, before and after a short but intensive training (13 one-hour lessons each, with 2 lessons a day). Conducted at the vocational school's psychophysiological laboratory and recorded by means of a dynamographic "Imbert-Amar" file, the tests recorded the backward gliding movement of the file (poussée arrière) as well as the total pressure exerted on the piece (pression totale sur la pièce). Two recording speeds were applied - the instant/ synchronic registration (tracé instantané) and interval recording (tracé sur enregistreur ralenti) - which generated a finger-shaped and a blade-of-grass pattern, respectively. The model performance by the instructor is visible as a steady and balanced—or call it a rhythmic and harmonious—chart, whereas the more or less irregular curves of the apprentices hint at, among other things, hesitant movements, a poor manipulation of the file, and bad body postures, reflecting the apprentices' individual "character." The personal deficiencies and, with them, the differences between the apprentices' performances seem to have faded (at least partly) as a result of the training, which helped the apprentices approach what was considered the standard or norm. By juxtaposing the pre- and post-training results, the poster thus becomes a kind of hymn, expressing a strong belief in the trainability of man and glorifying appliedscience approaches.

Amar also went beyond these "visible numbers" and, like many of his contemporaries who aspired to a kind of "structural objectivity," tried to organize his findings into more abstract and coherent structures-generalizable and predictive mathematical models, formulas, and differential equations - which made it possible to predict the "outcome" (if all the variables are known) or calculate the value of the missing variable. As Lorraine Daston and Peter Galison have pointed out, advocates of structural objectivity (often mathematicians,

celestial bodies" and that he "began with a theoretical belief in the moral superiority of bell-curve distributions"; see Lynn Fendler, "Bell Curve," in Encyclopaedia of Educational Theory, vol. 1, ed. Dennis C. Phillips (New York: Sage, 2014), 83-86, http://fendler.wiki. educ.msu.edu/Bell+Curve. See also Kevin Donnelly, Adolphe Quetelet, Social Physics and the Average Men of Science, 1796-1874 (Pittsburgh, PA: University of Pittsburgh Press, 2016).

78 In 1919, Amar wrote: "Statistics were one of our study methods; all our surveys, in various countries, cover more than 33,000 people, of both sexes, and-in terms of apprenticesnearly 700 children." See Amar, "Titres et travaux scientifiques," 11. 


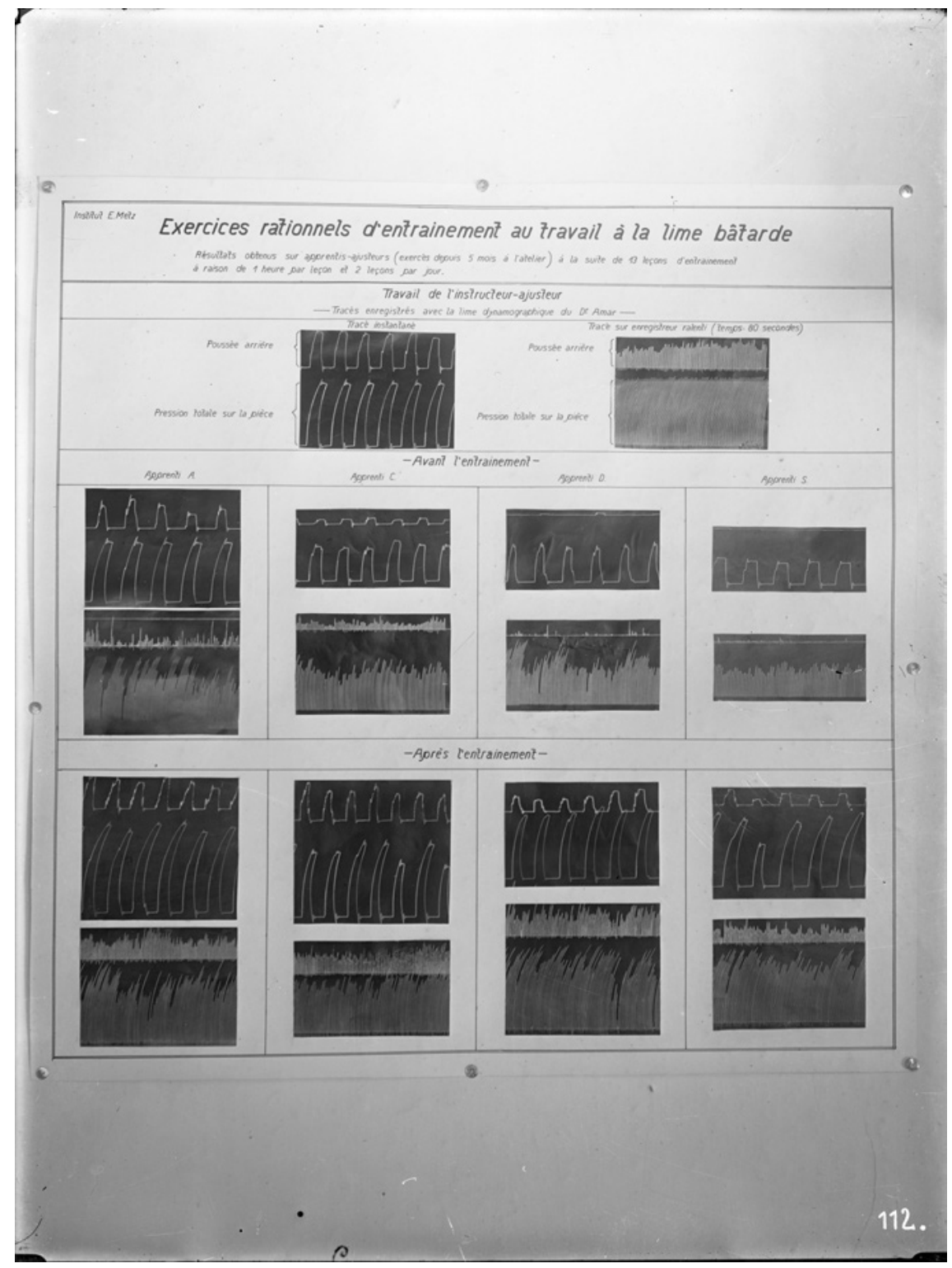

FIGURE 5.7 Poster displaying the filing test results of the instructor and four apprentices. Digital positive from glass plate negative.

(c) institut EMILE METZ. CNA COLLECTiON. 
physicists, and logicians) believed that taking refuge in these structures was the only way "to break out of the private mental world of individual subjectivity. In their view, science worthy of the name must be communicable to all, and only structures-not images, not intuitions, not mental representations of any kind — could be conveyed to all minds across time and space."79 In other words, representatives of structural objectivity "identified the "structures" as the core of objectivity." 80 Amar did so as well, while he tried to capture "universal laws" by means of a neutral language and applied, refined, and combined existing and/or developed new equations. ${ }^{81}$

If Amar imagined the ideal worker or human being as a man-machine hybrid with adjustable, removable, and replaceable mechanical "auxiliary organs"extensions which would open up new possibilities to achieve supra-natural perfection-then he imaged a similar future for scientific observers. ${ }^{82}$ In order to overcome their limitations of body and mind, the researchers, like the maimed soldiers, had to be equipped with mechanical extensions of their body and senses. Hence, in order to map the workers' or apprentices' physical and psychological functions, the observers too should not be limited by their physical

79 Daston and Galison, Objectivity, 254.

80 Ibid.

81 The Human Motor contains many of these formulas, such as equations representing man's maximum daily output $(\mathrm{T}=\mathrm{F} \times \mathrm{v} \times \mathrm{t})$ or the work done by the muscles of the leg $(\mathrm{R} \times$ $\mathrm{D}=\mathrm{T}=2 \mathrm{~F}$ d.) Amar explains the first equation, "The Maximum Work of Man," which he ascribed to the geometricians and natural philosophers Daniel Bernoulli and Euler Coulomb, as follows: "From the industrial point of view, the mechanical work estimated in kilogrammetres must be considered in most trades. ... This work is evaluated by determining the power of the subject, the product of his effort, his speed in unit time, a second, and by multiplying this power $(\mathrm{F} \times \mathrm{v})$ by the effective duration of the labour in seconds, whence: $\mathrm{T}=\mathrm{F} \times \mathrm{v} \times \mathrm{t}$. Particular values of these three factors can be found, so that the product $\mathrm{F} \times \mathrm{v} \times \mathrm{t}$ is a maximum. $\mathrm{T}$ will then represent man's greatest daily output." See Amar, The Human Motor, 178. As for the work done by the legs, he writes: "If F is the uniform pressure on each pedal [of a dynamographic cycle] and $\mathrm{d}$ is the diameter of the circle of the pedal, the work done [T] will be $\mathrm{F} \times \mathrm{d}$. Per stroke of the pedal (both legs working) it is approximately: $\mathrm{T}=2 \mathrm{~F} \mathrm{~d}$. This is the work performed by the legs, and is also the work done in advancing the loaded bicycle. It is clear that, by each stroke of the pedal the bicycle advances a distance $\mathrm{D}$, depending on the gear. If $\mathrm{R}$ is the sum of the resistances overcome (resistance to rolling, passice resistance of the bearings and of the transmission, and resistance of the air) then $\mathrm{R} \times \mathrm{D}=\mathrm{T}=2 \mathrm{~F}$. So that, knowing $\mathrm{T}$ or $\mathrm{R}$, we can deduce the value of the average pressure F on the pedals"; ibid., 304-5.

82 See Brown, "The Prosthetics of Management," 271. 
and mental capacities and instead use test equipment to achieve scientific objectivity. ${ }^{83}$ This cyborgization through registering apparatuses supplanted the earlier technique of recording the activity of the observed with the aid of the body-sensory and mental capacities of the observer and made it possible to discover a hidden cosmos of energy flow that had previously been imperceptible to the naked eye. Indeed, even small nuances in pressure, speed, exhaustion - too small to be felt or sensed by the test persons themselveswere now documented through lines or graphs. While the desired harmonious and efficient task performance was always endangered by the insidious approach of "fatigue," the process of "becoming tired" could now be traced before it afflicted the worker.

Inspired by the work of Kostelnick and Kimball, we argue that the graphic rhetorics and the representational quality of mechanical and structural measurement devices, as they have also been applied by Amar, created a kind of supra- or even augmented reality. ${ }^{84}$ In other words, Amar, through his mechanical registration and inscription devices, attempted to record a supra-natural, "mediated reality" that only existed because of his apparatuses. Indeed, this mechanical epiphany ennobled his scientific findings, guaranteed truth-value, and made the invisible visible to the eye and comprehensible to the mind of the observer as well as the observed. In his view, the graphs were also excellent learning tools, which made it possible for those observed to observe themselves - in an indirect, abstract, and de-bodied, mechanically mediated way. Amar's scientific cosmos at the time encompassed an innovative approach, combining a particular material-visual setting with specific technical terminology and rhetoric. It also included an at first sight bizarre test equipment, which was often self-made and fabricated from everyday objects. In addition, Amar's aesthetic language of graphs, numbers, and formulas must have created a kind of "scientist's black box," as research results were no longer based on material-physical evidence but on mechanically achieved abstraction..$^{85}$

The question then arises: What role did this "experimental system" force its audiences to play, how did it structure and dominate what the audiences were seeing and thinking?86 It probably further empowered the scientist-in

83 See De Bont, "Energie in de weegschaal," 26.

84 See Kostelnick and Kimball, "Introduction," 11-12.

85 See Bruno Latour, Science in Action: How to Follow Scientists and Engineers through Society (Cambridge, MA: Harvard University Press, 1987).

86 Hans-Jörg Rheinberger, "Epistemische Dinge," in Handbuch Materielle Kultur: Bedeutungen, Konzepte, Disziplinen, ed. Stefanie Samida, Manfred K. H. Eggert, and Hans Peter Hahn (Stuttgart: Metzler, 2014), 193-97. See also Herman, Priem, and Thyssen, "Body_Machine?” 


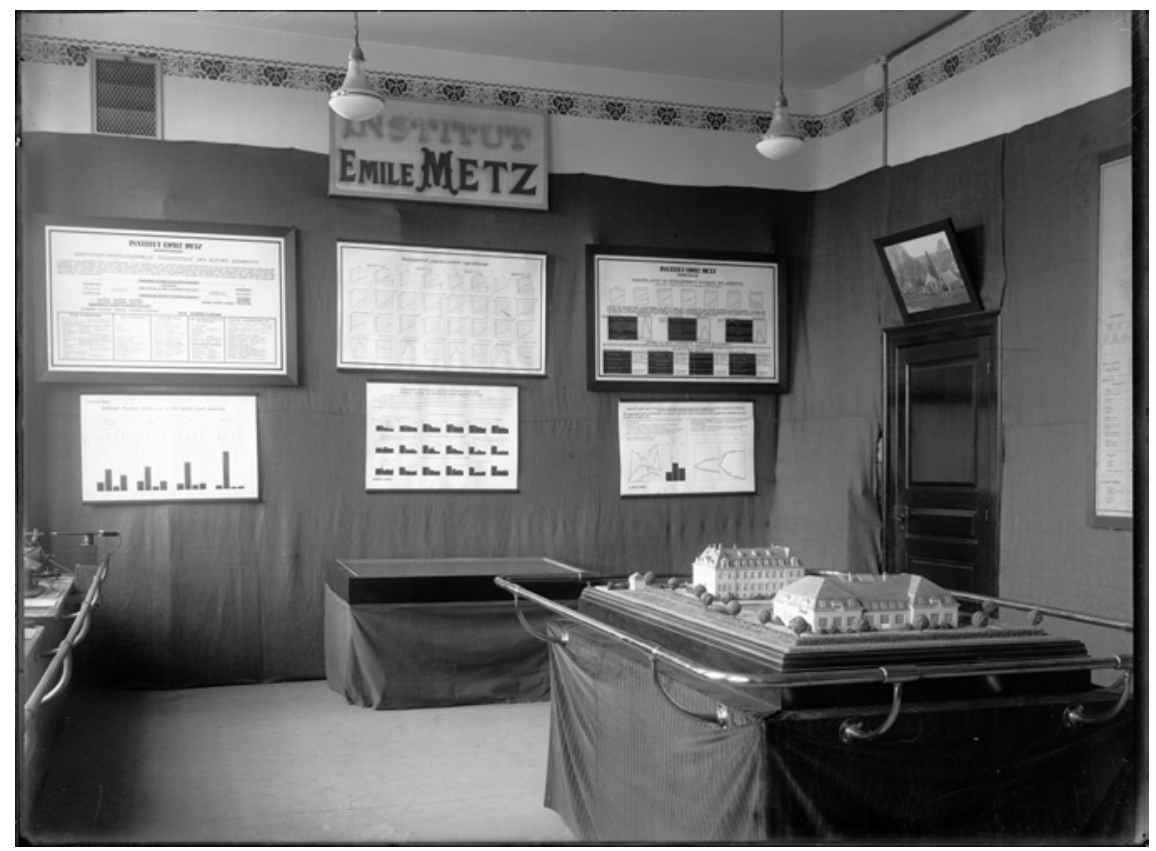

FIGURE 5.8 Graphs on the walls of the school's exhibition room. Digital positive from glass plate negative.

(C) INSTITUT EMILE METZ. CNA COLLECTION.

his/her role as an expert-and may have undermined the uninitiated's capacity to question or challenge the outcomes that were delivered by experts familiar with the rituals of mechanical objectivity. The graphs as well as the images of the test equipment and the psychophysiological laboratory were rhetorically used and staged as mechanical visualizations in the school's exhibition room (see fig. 5.8), depicting the institute as a Mecca of modern science and pedagogy and projecting a vast positivist faith in the "eye of the machine" and quantification. Abstract graphs as objective, supra-real visual arguments were used to strengthen the outcomes of research and the role of experts. As educational tools, they established a kind of augmented reality for those who were trained. Mechanical objectivity, as a way of observing and testing, thus entered the sphere of education, implying the promise of individualized and customized training. It was a promise that was, ironically, strongly rooted in and inspired by an economic reasoning in times of industrialist capitalism: the optimum performance of the worker for maximized productivity. 


\section{Sources and Bibliography}

Adam, Hans Christian, ed. Eadweard Muybridge: The Human and Animal Locomotion Photographs. Cologne: Taschen, 2014.

Amar, Jules. The Human Motor, or The Scientific Foundations of Labour and Industry. Translated by Elsie P. Butterworth and George F. Wright. London: George Routledge \& Sons; New York: E. P. Dutton \& Co., 1920.

Amar, Jules. “La rééducation des blessés et mutilés de la guerre.” Revue Scientifique 54 (1916): $363-67$.

Amar, Jules. Le devoir agricole et les blessés de guerre. Paris: Dunod et Pinat, 1917.

Amar, Jules. Le moteur humain et les bases scientifiques du travail professionnel. Paris: Dunod et Pinat, 1913/14.

Amar, Jules. Le rendement de la machine humaine: Recherches sur le travail. Paris: J.-B. Baillière, 1909 .

Amar, Jules. Organisation physiologique du travail. Paris: Dunod et Pinat, 1917.

Amar, Jules. "Physical and Psychological Tests-Organization of the Training of the Disabled." T. M. Canada—Special Bulletin (1916): 29-42.

Amar, Jules. The Physiology of Industrial Organisation and the Re-Employment of the Disabled. Edited by A. F. Stanley Kent. Translated by Bernard Miall. London: The Library Press Limited, 1918.

Amar, Jules. “Titres et travaux scientifiques." Unpublished manuscript, Faculté de Médecine de Paris, 1919, BIU Santé, Paris.

Amar, Jules, and Paul Painlevé. La prothèse et le travail de mutilés: Conférence faite pour les Oeuvres de Mutilés. Paris: Dunod et Pinat, 1916.

Blom, Philipp. Alleen de wolken: Cultuur en crisis in het Westen, 1918-1938. Translated by Pon Ruiter and Henny Corver. Amsterdam: De Bezige Bij, 2014.

Blom, Philipp. The Vertigo Years: Change and Culture in the West, 1900-1914. London: Phoenix, 2009.

Borella, Vincent. "Les corps entre mécanique et machines." In Corps et machines à l'âge industriel, edited by Laurence Guignard, Pascal Raggi, and Etienne Thévenin, 24958. Rennes: Presses Universitaires de Rennes, 2011.

Brown, Elspeth H. "The Prosthetics of Management: Motion Study, Photography, and the Industrialized Body in World War I America." In Artificial Parts, Practical Lives: Modern Histories of Prosthetics, edited by Katherine Ott, David Serlin, and Stephen Mihm, 249-81. New York: New York University Press, 2002.

Colas des Francs, Gilles. L'oeuvre de Jules Amar entre 1914-1918. Paris: Reprocopy, 1984.

Collard, Clément. "Que faire des 'héros vaincus'? - La rééducation professionnelle des mutilés de la Grande Guerre 1914-1940.” Master's thesis, Institut d'études politiques de Paris, 2014. 
Danziger, Kurt. Constructing the Subject: Historical Origins of Psychological Research. Cambridge: Cambridge University Press, 2002.

Daston, Lorraine, and Peter Galison. Objectivity. New York: Zone Books, 2007.

Daston, Lorraine, and Elizabeth Lunbeck. "Observing in New Ways: Techniques." In Histories of Scientific Observation, edited by Lorraine Daston and Elizabeth Lunbeck, 181-84. Chicago: University of Chicago Press, 2011.

De Bont, Raf. "Energie op de weegschaal: Vermoeidheidsstudie, psychotechniek en biometrie in België (1900-1945)." Belgisch Tijdschrift voor Nieuwste Geschiedenis/ Revue Belge d'Histoire Contemporaine 32, nos. 1-2 (2002): 23-71.

Depaepe, Marc. Zum Wohl des Kindes? Pädologie, pädagogische Psychologie und experimentelle Pädagogik in Europa und den USA, 1890-1940. Leuven: Leuven University Press; Weinheim: Deutscher Studien Verlag, 1993.

de Paeuw, Leo. Vocational Re-Education of Maimed Soldiers. Princeton, NJ: Princeton University Press, 1918.

Dobell, W. M. "Report on European Work." T. M. Canada—Special Bulletin (1916): 11-28. Donnelly, Kevin. Adolphe Quetelet, Social Physics and the Average Men of Science, 17961874. Pittsburgh, PA: University of Pittsburgh Press, 2016.

Dror, Otniel E. "Seeing the Blush: Feeling Emotions." In Histories of Scientific Observation, edited by Lorraine Daston and Elizabeth Lunbeck, 326-48. Chicago: University of Chicago Press, 2011.

Ekström, Anders. “'Showing at One View': Ferdinand Boberg's 'Statistical Machinery' and the Visionary Pedagogy of Early Twentieth-Century Statistical Display." Early Popular Visual Culture 6, no. 1 (2008): 35-46.

Fendler, Lynn. "Bell Curve." In Encyclopaedia of Educational Theory, vol. 1, edited by Dennis C. Phillips, 83-86. New York: Sage, 2014. http://fendler.wiki.educ.msu.edu/ Bell+Curve.

Ford, Henry. "Machinery, the New Messiah." Forum (1928): 359-64.

Freud, Sigmund. Civilization and Its Discontents. Translated by David McLintock. London: Penguin Books, 2004.

Friendly, Michael. "The Golden Age of Statistical Graphics.” Statistical Science 28, no. $4(2008): 502-35$.

Galtier-Boissière, Émile. Larousse médical illustré de guerre. Paris: Librairie Larousse, 1917.

Gleyse, Jacques, Charles Pigeassou, Anne Marcellini, Eric De Léséleuc, and Gilles BuiXuân. "Physical Education as a Subject in France (School Curriculum, Policies and Discourse): The Body and the Metaphors of the Engine-Elements Used in the Analysis of a Power and Control System during the Second Industrial Revolution." Sport, Education and Society 7 , no. 1 (2002): $5^{-23}$.

Gray, Chris Hables. Cyborg Citizen: Politics in the Posthuman Age. New York: Routledge, 2002. 
Haraway, Donna J. "A Manifesto for Cyborgs: Science, Technology, and Socialist Feminism in the 1980's." Socialist Review 80 (1985): 65-107.

Haraway, Donna J. “Modest_Witness @ Second_Millenium.” In The Social Shaping of Technology, 2nd ed., edited by Donald MacKenzie and Judy Wajcman, 41-49. Buckingham, UK: Open University Press, 1999.

Hayles, Katherine N. How We Became Posthuman. Chicago: University of Chicago Press, 1999.

Herman, Frederik. "Forging Harmony in the Social Organism: Industry and the Power of Psychometric Techniques." History of Education 43, no. 5 (2014): 592-614.

Herman, Frederik, Karin Priem, and Geert Thyssen. "Body_Machine? Encounters of the Human and the Mechanical in Education, Industry and Science." History of Education 46, no. 1 (2017): 108-27.

Herman, Frederik, Karin Priem, and Geert Thyssen. "Körper_Maschinen? Die Verschmelzung von Mensch und Technik in Pädagogik, Industrie und Wissenschaft." Jahrbuch für Historische Bildungsforschung 20 (2015): 47-75.

Hughes, Gordon, and Philipp Blom. Nothing but the Clouds Unchanged:Artists in World War I. Los Angeles: Getty Research Institute, 2014.

Jorland, Gérard, Annick Opinel, and George Weisz, eds. Body Counts: Medical Quantification in Historical and Sociological Perspectives/Perspectives historiques et sociologiques sur la quantification médicale. Montreal: McGill-Queen's University Press, 2005.

Kimball, Miles A., and Charles Kostelnick. Visible Numbers: Essays on the History of Statistical Graphics. Farnham, UK: Ashgate, 2016.

Klein, Alexandre. "Lire le corps pour percer l'âme': outils et appareils à l'aube de la psychologie scientifique à Nancy." In Corps et machines à l'âge industriel, edited by Laurence Guignard, Pascal Raggi, and Etienne Thévenin, 41-54. Rennes: Presses Universitaires de Rennes, 2011.

Klette, Reinhard, and Garry Tee. "Understanding Human Motion: A Historic Review." In Human Motion: Understanding, Modelling, Capture and Animation, edited by Bodo Rosenhahn, Reinhard Klette, and Dimitris Metaxas, 1-22. Dordrecht: Springer, 2008.

Kostelnick, Charles. "Melting-Pot Ideology, Modernist Aesthetics, and the Emergence of Graphical Conventions: The Statistical Atlases of the United States, 1874-1925." In Defining Visual Rhetorics, edited by Charles A. Hill and Marguerite Helmers, 215-42. Mahway, NJ: Lawrence Erlbaum Associates, 2004.

Latour, Bruno. Science in Action: How to Follow Scientists and Engineers through Society. Cambridge, MA: Harvard University Press, 1987.

Latour, Bruno, and Steve Woolgar. Laboratory Life: The Construction of Scientific Facts. Princeton, NJ: Princeton University Press, 1986.

McLennan, J. “Introduction.” T. M. Canada—Special Bulletin (1916): 5-9. 
Monod, Hugues. “Amar, Jules (1879-1935)." In Les professeurs du Conservatoire National des Arts et Métiers: Dictionnaire biographique 1794-1955, vol. 1, edited by Claudine Fontanon and André Grelon, 97-107. Paris: INRP/CNAM, 1994.

Monod, Hugues, and Janine Monod. "Jules Amar (1879-1935)." Histoire des sciences médicales 13, no. 3 (1979): 227-35.

Ouvrier-Bonnaz, Régis. "L'histoire des chaires du CNAM concernant l'Homme au travail (1900-1945) entre production de savoirs et engagement politique." Cahiers d'histoire: Revue d'histoire critique 111 (2010): 99-121.

Panchasi, Roxanne. Future Tense: The Culture of Anticipation in France between the Wars. Ithaca, NY: Cornell University Press, 2009.

Panchasi, Roxanne. "Reconstructions: Prosthetics and the Rehabilitation of the Male Body in World War I France." Differences: A Journal of Feminist Cultural Studies 3, no. 3 (1995): 109-40.

Patzel-Mattern, Katja. "Menschliche Maschinen-Maschinelle Menschen? Die industrielle Gestaltung des Mensch-Maschine-Verhältnisses am Beispiel der Psychotechnik und der Arbeit Georg Schlesingers mit Kriegsversehrten.” Würzburger medizinhistorische Mitteilungen 24 (2005): 378-90.

Pitsos, Nicolas. "Le moteur humain en panne s'affiche: le corps épuisé au tournant du XIXe siècle." In Corps et machines à l'âge industriel, edited by Laurence Guignard, Pascal Raggi, and Etienne Thévenin, 289-300. Rennes: Presses Universitaires de Rennes, 2011.

Poos, Françoise. "Photography as a Space for Constructing Subjectivities: Luxembourg's Steel Dynasties and the Modern Workforce as Seen through the Glass Plate Negatives from the Institut Emile Metz." In this volume.

Popkewitz, Thomas S. "The Empirical and Political 'Fact' of Theory in the Social and Education Sciences." In Making a Difference in Theory: The Theory Question in Education and the Education Question in Theory, edited by Gert Biesta, Julie Allan, and Richard Edwards, 13-29. London: Routledge, 2014.

Porter, Theodore M. Trust in Numbers: The Pursuit of Objectivity in Science and Public Life. Princeton, NJ: Princeton University Press, 1995.

Priem, Karin, and Frederik Herman. 'Sensuous Geographies' in the 'Age of Steel': Educating Future Workers' Bodies in Time and Space (1900-1940)." In this volume.

Rabinbach, Anson. The Human Motor: Energy, Fatigue and the Origins of Modernity. Berkeley: University of California Press, 1992.

Rheinberger, Hans-Jörg. “Epistemische Dinge.” In Handbuch Materielle Kultur: Bedeutungen, Konzepte, Disziplinen, edited by Stefanie Samida, Manfred K. H. Eggert, and Hans Peter Hahn, 193-97. Stuttgart: Metzler, 2014.

Ribeill, Georges. "Les débuts de l'ergonomie en France à la veille de la Première Guerre mondiale." Le mouvement social 113 (1980): 3-36.

Strand, Paul. "Photography and the New God." Broom 3, no. 4 (1922), 252-58. 
“The Training of Maimed Soldiers." The Engineer, June 9, 1916, 472-73.

Valentin, Michel. Travail des hommes et savants oubliés: Histoire de la médecine du travail, de la sécurité et de l'ergonomie. Paris: Editions Docis, 1978.

Vandewalle, Henry, and Tarak Driss. "Friction-Loaded Cycle Ergometers: Past, Present and Future." Cogent Engineering 2 (2015): 1-35.

Vatin, François. "Du travail à la fatigue, genèse et échec de la psycho-physiologie du travail." Bulletin de psychologie 49, no. 425 (1996): 520-29.

Vatin, François. "Les 'sciences du travail': une tentative de résolution positiviste de la question sociale." Bulletin de psychologie 61, no. 496 (2008): 331-40.

Verstraete, Pieter, and Frederik Herman. "A Plea for Commonality: Disability History, Discourses of Rehabilitation, and the Individual." Asclepio: Revista de Historia de la Medicina y de la Ciencia 68, no. 2 (2016): n.p. 